\title{
Fatty acid synthase affects expression of ErbB receptors in epithelial to mesenchymal transition of breast cancer cells and invasive ductal carcinoma
}

\author{
TINGTING CHEN $^{1 *}$, LAN ZHOU $^{1 *}$, HUA LI $^{1}$, YUAN TIAN $^{2}$, JUNQIN LI $^{1}$, \\ LIHUA DONG $^{1}$, YUHUA ZHAO ${ }^{1}$ and DAPENG WEI ${ }^{1}$ \\ ${ }^{1}$ Department of Basic and Forensic Medicine; ${ }^{2}$ West China School of Medicine/West \\ China Hospital, Sichuan University, Chengdu, Sichuan 610041, P.R. China
}

Received October 25, 2015; Accepted June 9, 2017

DOI: $10.3892 / \mathrm{ol} .2017 .6954$

\begin{abstract}
The aim of the presentstudy was to investigate changes in the expression of ErbBs during epithelial-mesenchymal transition (EMT) of breast cancer cells and its association with the expression of fatty acid synthase (FASN). MCF-7-MEK5 cells were used as the experimental model, while MCF-7 cells were used as a control. Tumor cells were implanted into nude mice for in vivo analysis. Cerulenin was used as a FASN inhibitor. Reverse transcription-polymerase chain reaction and western blot analysis were used to detect expression levels of FASN and ErbB1-4. Immunohistochemistry was used to detect the expression of FASN and ErbB1-4 in 58 invasive ductal carcinomas (IDC), as well as their association with clinicopathological characteristics. The expression of FASN and ErbB1-4 in MCF-7-MEK5 cells and tumor tissues increased significantly compared with controls $(\mathrm{P}<0.001)$. Inhibition of FASN by cerulenin resulted in a significant decrease in expression of ErbB1, 2 and $4(\mathrm{P}<0.001)$, whereas
\end{abstract}

Correspondence to: Professor Hua Li, Department of Basic and Forensic Medicine, Sichuan University, 17, Section 3, South Renmin Road, Chengdu, Sichuan 610041, P.R. China

E-mail: dochuali@126.com

*Contributed equally

Abbreviations: IDC, invasive ductal carcinoma; FASN, fatty acid synthase; EMT, epithelial-mesenchymal transition; ErbB, human epidermal growth factor receptor; EGFR, epidermal growth factor receptor; HER-2/neu, human epidermal growth factor receptor 2; ER, estrogen receptor; PR, progesterone receptor; VEGF, vascular endothelial growth factor; VEGFR2, vascular endothelial growth factor receptor 2; MEK5, mitogen-activated protein kinase (MAPK) kinase 5; ERK1/2, extracellular signal-regulated kinase 1/2; AKT, protein kinase $\mathrm{B}$

Key words: epithelial-mesenchymal transition, fatty acid synthase, ErbB1-4, breast cancer, clinicopathological characteristics there was no evident change in ErbB3. In IDC samples, the expression of FASN and ErbB1-4 increased considerably in lymph node metastases compared with non-lymph node metastases $(\mathrm{P}<0.05)$. ErbB2 expression increased in advanced clinical stages (II, III and IV) of IDC and in tumors with larger diameters $(\mathrm{P}<0.05)$. The expression of ErbB3 increased in ER-positive tumors $(\mathrm{P}<0.05)$. Additionally, a positive association between the expression of FASN and ErbB1, 2 and 4 was observed $(\mathrm{P}<0.05)$. FASN activates ErbB1, 2 and 4, and their dimers, which are polymerized via the microstructural domain of the cell membrane. This may initiate EMT and consequentlyincrease the invasion and migration of cancer cells. However, ErbB3 may also affect tumor progression via a FASN-independent pathway.

\section{Introduction}

Epithelial-mesenchymal transition (EMT) refers to the process by which differentiated epithelial cells transform into mesenchymal cells by undergoing various biochemical changes (1). In tumors, EMT involves a number of processes, including invasion, metastasis, drug resistance and development of anti-apoptotic features, which are the primary causes of breast cancer-associated mortality.Successful inhibition of these processes is expected to significantly improve breast cancer prognosis (2). Fatty acid synthase (FASN) is a key enzyme that catalyzes the synthesis of long-chain saturated fatty acids (3). Previous studies demonstrated that whenbreast cancer cells underwent EMT, FASN expressionincreased (4), and EMT was reversed when FASN was silenced with FASN short hairpin. (5). Osthole, an FASN inhibitor, was able to eliminate phenotypes associated with EMT induced by hepatocyte growth factor, including migration, invasion and metastasis in breast cancer cells (6). Therefore, FASN may serve an important role in EMT, but the mechanism is unclear.

Vazquez-Martin et al (7) determined that overexpression of FASN and the synthesis and aggregation of endogenous fatty acid induced the transformation of epithelial cells to a tumor phenotype. This change was dependent on ErbB1/ErbB2, which indicated an association between ErbBs and FASN during EMT of tumor cells. The ErbB family, including epidermal 
growth factor receptor (EGFR; ErbB1, HER1), ErbB2 (Neu, HER2), ErbB3 (HER3) and ErbB4 (HER4) (8), has been shown to induce morphological changes, survival, invasion and EMT in cells (9). ErbBs that are anchored in membrane lipid rafts dimerize and become activated, thereby initiating relevant downstream signaling pathways that induce EMT characteristics in tumors (10). Destruction of lipid rafts and reduced activity of the downstream signaling molecules protein kinase B (Akt), extracellular signal-regulated kinase 1/2 (ERK1/2) and the FASN protein by docosahexaenoic acid, resulted in inhibition of the ErbB2 signaling pathway and apoptosis of transformed human mammary epithelial cells (11). FASN and its end product palmitate are important components of lipid synthesis (12). Therefore, it was hypothesized that FASN regulates the expression of ErbBs by affecting the structure of membrane lipid rafts, and consequently affects downstream signal pathways and the EMT phenotype. Due to the complex structure or ErbBs, and functions in cancer, several studies have focused on ErbB1 and ErbB2 in recent years and the development of targeted inhibitors as a means of effective cancer treatment (13-15). However, tumors have acquired resistance to those targeted therapeutics (16). Whether ErbB3 or ErbB4 have any significant function in cancer is debated (17-20), and their association with the other ErbBs, FASN and clinicopathological characteristics of breast cancer is currently unclear. The present study investigated these associations using MCF-7-MEK5 and its tumor tissues, which exhibited the EMT phenotype. In the present study, the non-EMT isogenic MCF-7 cell line and its tumor tissues served as controls. Cerulenin, a specific inhibitor of FASN (21), was used to assess the role of FASN. Western blot analysis was performed to detect changes in the expression of FASN and ErbBs. Immunohistochemistry was used to detect the expression of FASN and ErbBs in 58 invasive ductal carcinoma samples and the association of FASN expression withclinicopathological characteristics was investigated.

\section{Materials and methods}

Ethical approval. The University of Sichuan Medical Institutional Review Board approved the present study (approval no. K2015027). Written informed consent was obtained from all study participants prior to participation. The study was performed according to the principles in the Declaration of Helsinki. All animal experiments were performed in strict accordance with the recommendations in the guide for the care and use of laboratory animals by the authority of the People's Republic of China and approved by the Institutional Animal Care and Use Committeeat Sichuan University (Sichuan, China).

Patients. A total of 58 breast IDCs were collected from patients subsequent to obtaining informed consent, at the Department of Breast Surgery, West China Hospital of Sichuan University (Sichuan, China) between May 2010 and Feb 2013. The mean age of 58 patients was $50.4 \pm 11.3$ years, and none of them had undergone chemotherapy or radiotherapy prior to collection. All specimens were fixed with $40 \mathrm{~g} / 1$ formaldehyde at $4^{\circ} \mathrm{C}$ for $24 \mathrm{~h}$, embedded with paraffin and sectioned into serial slices (thickness, $4 \mu \mathrm{m}$ ).
Cell culture. Human breast cancer MCF-7 cells were purchased from the Cell Bank of the Chinese Academy of Sciences (Shanghai, China), and MCF-7-MEK5 (22) cells were obtained from the Department of Immunology Laboratory, West China College of Basic and Forensic Medicine of Sichuan University (Sichuan, China). The cells were cultured in high glucose Dulbecco's modified Eagle's medium complete medium (catalog no. SH30022.01B), containing $100 \mathrm{ml} / \mathrm{l}$ fetal bovine serum (catalog no. SV30087.01) and $10 \mathrm{ml} / 1$ penicillin and streptomycin (catalog no. SV30010) (all from HyClone; GE Healthcare, Chicago, IL, USA) at $37^{\circ} \mathrm{C}$ under $50 \mathrm{ml} / 1 \mathrm{CO}_{2}$ saturated humidity.

Establishment of the breast cancer orthotopic injection model. A total of 18 specific pathogen-free BALB/c nude mice (5 weeks old; female; weighing 18-20 g) were provided by the Experimental Animal Center at the West China School of Medicine, Sichuan University (Sichuan, China). All mice were housed singly with environmental conditions maintained at $21 \pm 1^{\circ} \mathrm{C}$ with a relative humidity of $50 \pm 10 \%$ and 15 air charges/h under a 12-h light cycle (12 h of light followed by $12 \mathrm{~h}$ of dark). Sawdust and wood shavings were used as bedding. The mice were randomly divided into two groups with 9 mice in each group. Each group was randomly divided into an experimental subgroup (6 mice) and a control group (3 mice). Mice were allowed free access to food and water, and had a $12 \mathrm{~h} \mathrm{light/dark} \mathrm{cycle.} \mathrm{With} \mathrm{an} \mathrm{implanted} 17$ $\beta$-estradiol (E2) pellet $(0.36 \mathrm{mg} / \mathrm{mouse}$; Sigma-Aldrich; Merck KGaA, Darmstadt, Germany), digested MCF-7 and MCF-7-MEK5 cells were diluted to $1 \times 10^{7} / \mathrm{ml}$ with Hank's balanced salt solution (14025092; Thermo Fisher Scientific, Inc., Waltham, MA, USA), and orthotopically injected under the mammary fat pads of mice $(0.1 \mathrm{ml} / \mathrm{mouse})$. The mice were raised in fan-filtered units. When the tumor grew to 100 $\mathrm{mm}^{3}$, the E2 pellets were removed and $160 \mathrm{mg} / \mathrm{d} / \mathrm{kg}$ cerulenin (BML-G237-0025; Biomol GmbH, Hamburg, Germany) was administered by intraperitoneal injection to mice in the experimental group for 10 consecutive days. All mice were carefully observed throughout the experimental period and should signs consistent with severe suffering have been detected, those mice would have been sacrificed immediately. At 5 days following the last injection, the mice were sacrificed by cervical dislocation and their tumor tissues were extracted.

Immunohistochemistry. Breast cancer tissues were fixed with $40 \mathrm{~g} / 1$ formaldehyde at $4^{\circ} \mathrm{C}$ for $24 \mathrm{~h}$, embedded in paraffinand sectioned into serial slices (thickness, $4 \mu \mathrm{m}$ ). Immunohistochemistry was performed using the SPlink Detection kit (catalog no. SP9000; ZSGB-BIO; OriGene Technologies, Inc., Beijing, China), according to themanufacturer's instructions. For negative control, PBS solution replaced primary antibodies. The following primary antibodies were used: Mouse anti-human FASN (1:300; catalog no. sc-55580; Santa Cruz Biotechnology, Inc., Dallas, TX, USA) and rabbit anti-human ErbB-1 (1:200; catalog no. B8501; ImmunoWay Biotechnology Company, Plano, TX, USA), ErbB-2 (1:200; catalog no. 29D8; Cell Signaling Technology, Inc. Danvers, MA, USA), ErbB-3 (1:200; catalog no. A0436; ABclonal Biotech Co., Ltd. Cambridge, MA, 
Table I. Primers involved in reverse transcription-polymerase chain reaction.

\begin{tabular}{clc}
\hline $\begin{array}{c}\text { Gene } \\
\text { name }\end{array}$ & \multicolumn{1}{c}{ Primer sequence (5'-3') } & $\begin{array}{c}\text { Product } \\
\text { length } \\
\text { (bp) }\end{array}$ \\
\hline $\begin{array}{c}\text { GAPDH } \\
\text { F }\end{array}$ & CTGCCCCCTCTGCTGATG & 150 \\
R & TCCACGATACCAAAGTTGTCAT & \\
FASN & & 458 \\
F & GCCTACTACATCGACTGCATCA & \\
R & TACTTGGCCTTGGGTGTGTACT & \\
ErbB1 & & 476 \\
F & CCCTCAAGGAGATAAGTAATGG & \\
R & GTACTTCCAGACCAGGGTGTTGT & \\
ErbB2 & & 544 \\
F & ACAGTCTACAAGGGCATCTGGA & \\
R & CCCACACAGTCACACCATAACT & \\
ErbB3 & & 251 \\
F & AGGCTTTCAACATCCCACCTC & \\
R & GCCATTACAGCAGGAGTCATC & \\
ErbB4 & & 349 \\
F & CTACGAGAGGTGTAGGGTGGT & \\
R & GAGCAGTCTTGGGTCATCATC & \\
\hline
\end{tabular}

ErbB, human epidermal growth factor receptor; FASN, fatty acid synthase; F, forward; R, reverse.

USA) and ErbB-4 (1:200; catalog no. A0749; ABclonal Biotech Co., Ltd.) monoclonal antibodies. The paraffin sections were deparaffinizedin water. For antigen retrieval, the sections were heated at $95-98^{\circ} \mathrm{C}$ for $10 \mathrm{~min}$. The sections were subsequently treated with $5 \mathrm{ml} / 1$ hydrogen peroxide, and goat serum (SPlink Detection kit; ZSGB-BIO; Ori-Gene Technologies, Inc.) was added to each section to block endogenous peroxidase activity. The paraffin-embedded blocks were incubated at $37^{\circ} \mathrm{C}$ for $30 \mathrm{~min}$. The sections were then incubated overnight at $4^{\circ} \mathrm{C}$ with primary antibodies: Mouse anti-human FASN (1:300; cat. no. sc-55580; Santa Cruz Biotechnology, Inc.) and rabbit anti-human ErbB-1 (1:200; cat. no. B8501; ImmunoWay Biotechnology Company, Plano, TX, USA), ErbB-2 (1:200; cat. no. 29D8; Cell Signaling Technology, Inc.), ErbB-3 (1:200; cat. no. A0436; ABclonal Biotech Co., Ltd. Cambridge, MA, USA) and ErbB-4 (1:200; cat. no. A0749; ABclonal Biotech Co., Ltd.) monoclonal antibodies, followed by incubation with the secondary and tertiary antibodies (SPlink Detection kit; ZSGB-BIO; Ori-Gene Technologies, Inc.), at $37^{\circ} \mathrm{C}$ for $30 \mathrm{~min}$. 3,3'-diaminobenzidine (Inspissation DAB kit; catalog no. ZLI-9032; ZSGB-BIO; Ori-Gene Technologies, Inc.) was used to stain the tissue sections at room temperaturefor between 3 and $5 \mathrm{~min}$. The sections were subsequently stained with $2 \mathrm{~g} / \mathrm{l}$ hematoxylin at room temperature for $4 \mathrm{~min}$, differentiated with hydrochloric acid in alcohol for $5 \mathrm{sec}$, flushed with tap water for $40 \mathrm{~min}$, followed by dehydration, clearing and mounting.
Analysis of immunohistochemical (IHC) staining results. A total of five random fields of view were assessed under $\mathrm{x} 400$ magnification (Nikon ECLIPSE Ti-U, light microscope; Nikon Corporation, Tokyo, Japan). The intensity of staining and the percentage of positive cells were then recorded. Total points were determined by adding the value for staining intensity and the percentage of positive cells for each field of view. The sections were divided according to staining intensity into negative, light brown, brown and sepia, and scored as 0, 1,2 and 3, respectively. In terms of the percentage of positive cells, the sections were categorized as negative, $<10 \%, 11-50 \%, 51-80 \%$ and $>80 \%$, and scored as $0,1,2,3$ and 4 , respectively. Sections with total points $<4$ were considered negative (-), 4 points as weak-positive (+), 5 points as moderately-positive $(++)$ and $\geq 6$ points as strongly-positive (+++).

Reverse transcription-polymerase chain reaction (RT-PCR). Total RNA was extracted from cells/tissues using Tripure (cat. no. 1667165001; Roche Diagnostics, Basel, Switzerland), and reverse transcription to cDNA was performed using the RevertAid First Strand cDNA Synthesis kit (cat. no. K1621; Fermentas; Thermo Fisher Scientific, Inc.), according to the manufacturer's protocol. Primer sequences (Table I) were designed using the online software Primer3 (version 0.4.0; Whitehead Institute, Cambridge, MA, USA). Primer sequence specificity was verified using the Basic Local Alignment Search Tool (blast.ncbi.nlm.nih.gov/Blast.cgi), and the primers were synthesized by Shanghai Bioengineering Co. (Shanghai, China). RT-PCR was performed according to the manufacturer's protocol (cat. no. k0221; Fermentas; Thermo Fisher Scientific, Inc.). The thermocycling conditions were as follows: $95^{\circ} \mathrm{C}$ for $10 \mathrm{~min}$, followed by 40 cycles of $95^{\circ} \mathrm{C}$ for $15 \mathrm{sec}$, $60^{\circ} \mathrm{C}$ for $30 \mathrm{sec}$ and $72^{\circ} \mathrm{C}$ for $30 \mathrm{sec}$. The primer annealing temperature was $60^{\circ} \mathrm{C}$ for all RT-PCR procedures performed. Data were analyzed according to the $2^{-\Delta \Delta C q}$ method (23), and all experiments were repeated three times.

Western blot analysis. Proteins extracted from MCF-7 and MCF-7-MEK5 cellsusing an radioimmunoprecipitation assaylysis buffer (cat. no. P0013B; Beyotime Institute of Biotechnology, Shanghai, China) were quantified and then denatured at $100^{\circ} \mathrm{C}$ for $5 \mathrm{~min}$. SDS-PAGE ( $8 \%$ gel) was performed, with $30 \mu \mathrm{g}$ protein loaded into each well of the gel. The proteins were then transferred to a $0.2 \mu \mathrm{m}$ polyvinylidene fluoride membrane (cat. no. 162-0177; Bio-Rad Laboratories, Inc., Hercules, CA, USA), using a semi-dry electrophoresis apparatus for $90 \mathrm{~min}$ (FASN) or $40 \mathrm{~min}$ (ErbB1, ErbB2, ErbB3 and ErbB4 antibodies) and then blocked with $50 \mathrm{ml} / 1$ low-fat milk solution at room temperaturefor $1 \mathrm{~h}$. The membrane was then rinsed with 1X TBS with Tween-20 (TBST) and incubated with primary antibodies against ErbB1 (dilution, 1:200; cat. no. B8501; ImmunoWay Biotechnology), ErbB2 (dilution, 1:500; cat. no. 29D8; Cell Signaling Technology, Inc.), ErbB3 (dilution, 1:500; cat. no. A0436; ABclonal Biotech Co., Ltd., Woburn, MA, USA) and ErbB4 (dilution, 1:500; cat. no. A0749; ABclonal Biotech Co., Ltd.) or FASN (dilution, 1:1,000; cat. no. sc-5558; Santa Cruz Biotechnology, Inc.) overnight at $4^{\circ} \mathrm{C}$, or primary antibody against $\beta$-actin (dilution, 1:1,000; cat. no. ab8227; Abcam, Cambridge, MA, USA) at room temperature for $2 \mathrm{~h}$. Membranes were rinsed again 

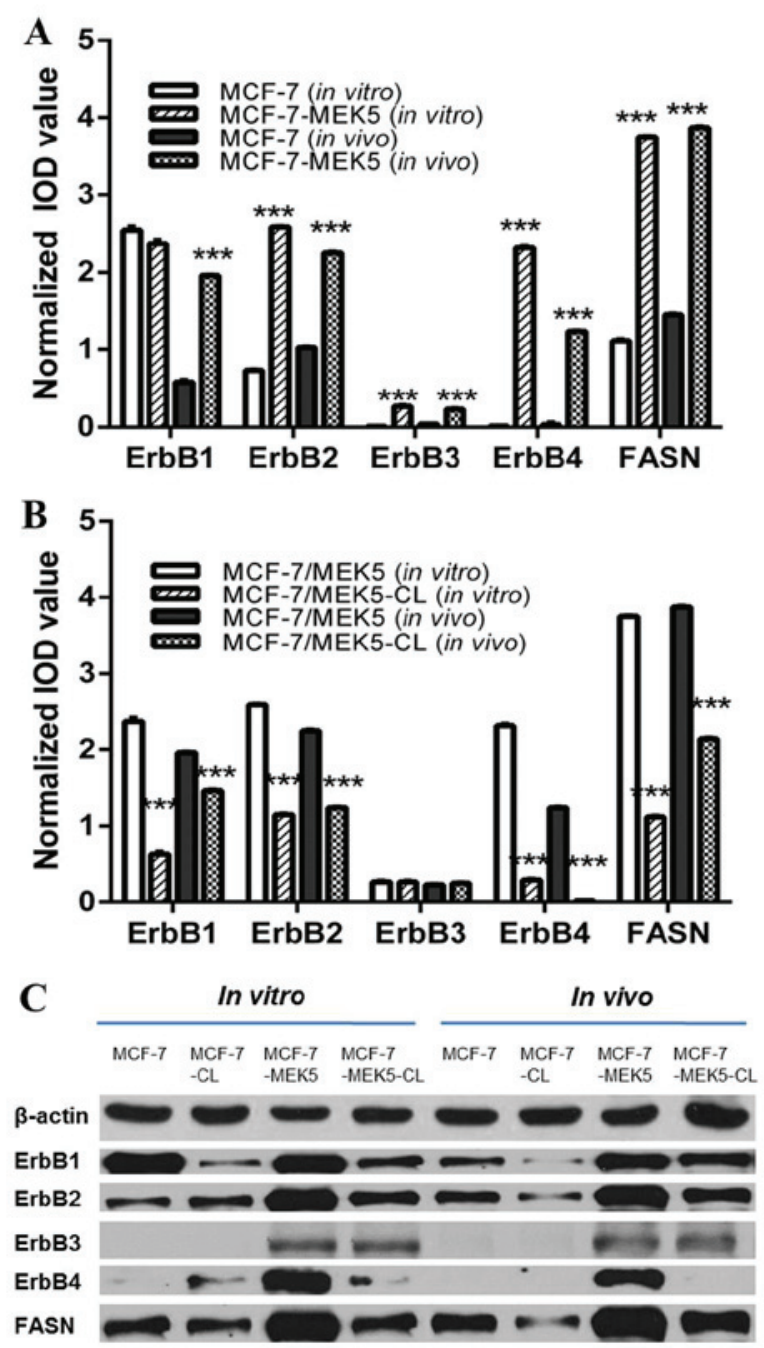

Figure 1. (A) Reverse transcription-polymerase chain reaction results indicated that the levels of ErbBs and FASN mRNA expression were upregulated in MCF-7-MEK5 cells/tissues compared with MCF-7 control cells/tissues. ${ }^{* * *} \mathrm{P}<0.001$.(B) FASN inhibition by cerulenin treatment decreased the mRNA expression of ErbB1, ErbB2 and ErbB4 in MCF-7-MEK5 cells and tumor tissues. ${ }^{* * *} \mathrm{P}<0.001$. (C) Western blotting results showed that the levels of ErbBs and FASN protein expression were upregulated in MCF-7-MEK5 cells and tumor tissues when compared with MCF-7 cells and tumor tissues. FASN inhibition by cerulenin treatment decreased the protein expression levels of ErbB1, ErbB2 and ErbB4 in MCF-7-MEK5 cells and tumor tissues. IOD, integrated optical density; CL, cerulenin.

with 1X TBST. Horseradish peroxidase-labeled secondary antibodies (1:3,000; anti-mouse; cat. no. 170-6516; 1:3,000; anti-rabbit; cat. no. 170-6515; Bio-Rad Laboratories, Inc.) were added to the membrane and incubated at room temperature for $1 \mathrm{~h}$. Pierce ${ }^{\mathrm{TM}}$ ECL Western Blotting Substrate kit (cat. no. 32209; Thermo Fisher Scientific, Inc.) was used to detect target bands, which was performed according to the manufacturer's protocol.

Statistical analysis. The data are presented as the mean \pm standard deviation. RT-PCR data were analyzed by using GraphPad Prism version 5.0 for Windows (GraphPad Software, Inc. La Jolla, CA, USA). A Student's t-test was used to detect the differences between groups. Immunohistochemical staining data were analyzed using SPSS 13.0 statistical software (SPSS, Inc.
Chicago, IL, USA). The nonparametric rank sum test was used to detectinter-block differences in pathological characteristics and a Spearmen correlation analysis was applied to the correlation analysis of positive expression between FASN and ErbB1-4. $\mathrm{P}<0.05$ was considered to indicate a statistically significant difference.

\section{Results}

$m R N A$ and protein expression of ErbBs in MCF-7 and MCF-7-MEK5 cell lines and tumor tissues. RT-PCR and western blot analyses were used to assess the differential expression of FASN and ErbBs in MCF-7 and MCF-7-MEK5 cell lines and tumor tissues. The FASN inhibitor, cerulenin (with $20 \mu \mathrm{g} / \mathrm{ml}$ for $24 \mathrm{~h}$ ), was added to cells in order to determine the effect of FASN inhibition on the expression of ErbBs. Compared with MCF-7 control cells, the levels of ErbB2-4 and FASN mRNA expression were significantly upregulated in MCF-7-MEK5 cells. Compared with MCF-7 cells, the expression of ErbB1, ErbB2, ErbB3, ErbB4 and FASN was 0.92 \pm 0.04 , $3.54 \pm 0.06,28.1 \pm 1.20,178 \pm 10.6$ and $3.45 \pm 0.11$-fold greater in MCF-7-MEK5 cells, respectively (Fig. 1A). FASN inhibition by cerulenin treatment resulted in a significant decreased expression of ErbB1, ErbB2 and ErbB4 in MCF-7-MEK5 cells. Compared with MCF-7 cells, the expression of ErbB1, ErbB2, ErbB3 and ErbB4 decreased by $0.27 \pm 0.02,0.44 \pm 0.00$, $1.06 \pm 0.01$ and $0.13 \pm 0.01$-fold in MCF-7-MEK5 cells, respectively. The expression of ErbBs and FASN mRNA was also upregulated in MCF-7-MEK5 tumor tissues compared with MCF-7 cells.Compared with MCF-7 tumor tissues, the expression of ErbB1, ErbB2, ErbB3, ErbB4 and FASN was 3.37 \pm 0.19 , $2.19 \pm 0.03,5.57 \pm 0.24,15.6 \pm 1.8$ and $2.25 \pm 0.07$-fold greater, in MCF-7-MEK5 cells, respectively. Analysis of tumors from cerulenin-treated mice revealed that the mRNA expression of ErbB1, ErbB2, ErbB3 and ErbB4 decreased by $0.75 \pm 0.01$, $0.57 \pm 0.02,1.09 \pm 0.01$ and $0.013 \pm 0.001$-fold, respectively, compared with untreated control mice (Fig. 1B).

At the protein level, the expression of ErbB1 was similar in MCF-7 and MCF-7-MEK5 cells. However, ErbB1 expression was markedly upregulated in MCF-7-MEK5 tumor tissues when compared with that of MCF-7 tumor tissues (Fig. 1C). ErbB1 expression was markedly downregulated in cerulenin-treated MCF-7-MEK5 cells and tumor tissues compared with MCF-7 cells. ErbB2 protein expression was higher in MCF-7-MEK5 cells and tumor tissues compared with the expression in MCF-7 cells. Expression of ErbB2 protein was markedly decreased in MCF-7-MEK5 cells and tissues with cerulenin treatment.

No ErbB3 protein expression was observed in MCF-7 cells and tumor tissues, and there was very low expression in MCF-7-MEK5 cells and tumor tissues. No significant change in ErbB3 was observed in cerulenin-treated MCF-7-MEK5 cells and tissues.

A very low ErbB4 expression was also observed in MCF-7 cells, and it was not detected in the tumor tissues. However, ErbB4 was highly expressed in MCF-7-MEK5 cells and tumor tissues, and cerulenin treatment markedly decreased its expression in this cell line.

Taken together, the present results suggestedan association between the expression of ErbBs 1, 2 and 4, and 


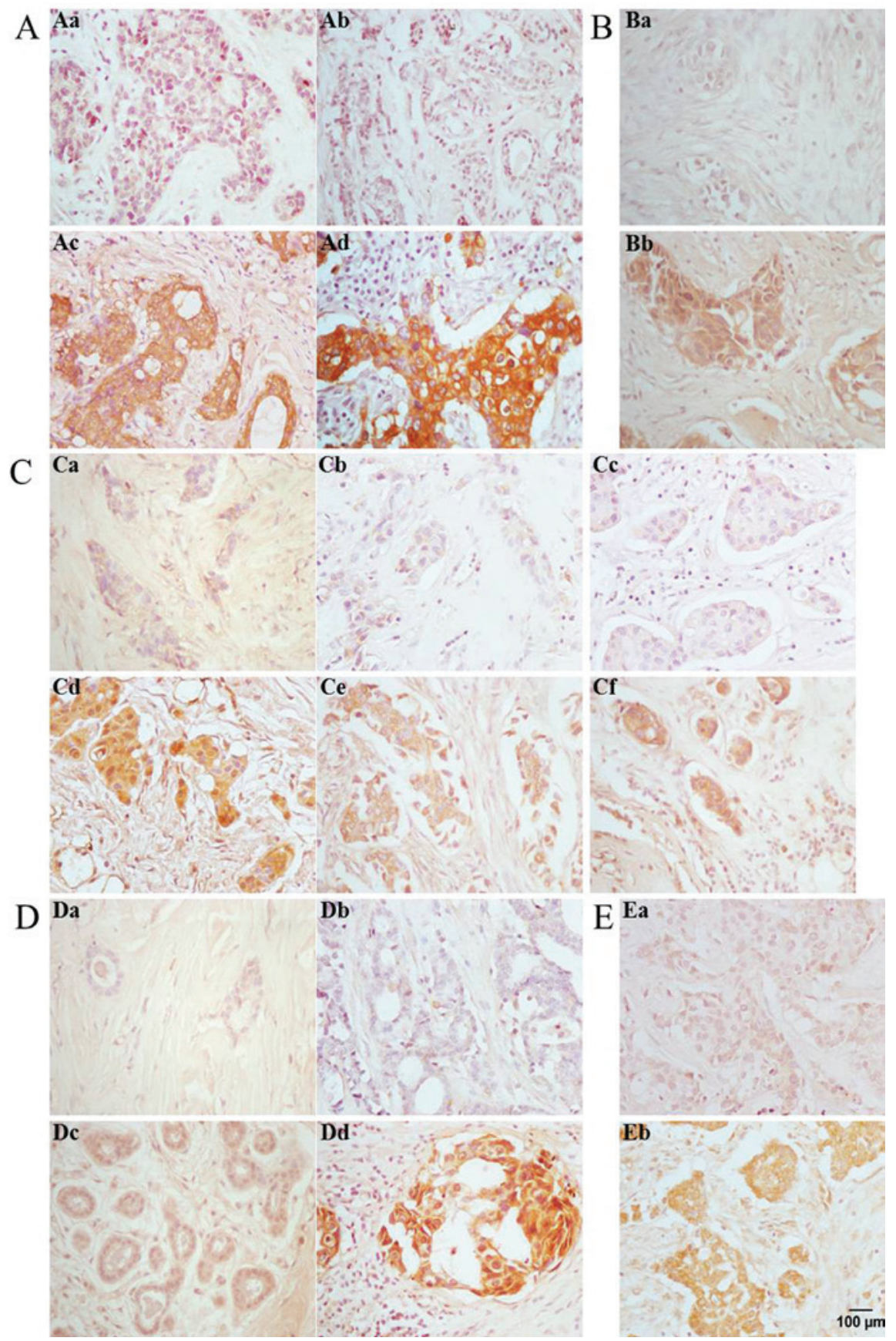

Figure 2. IHC staining. (A) IHC staining showed FASN expression in IDC. (Aa) Lymph node metastasis-negative IDC; (Ab) Lymph node metastasis-positive IDC; (Ac) IDC size $\leq 2 \mathrm{~cm}$; (Ad) IDC size $>2 \mathrm{~cm}$. (B) IHC staining showed the expression of ErbB1 in IDC. (Ba) Lymph node metastasis-negative IDC; (Bb) Lymph node metastasis-positive IDC. (C) IHC staining showed the expression of ErbB2 in IDC. (Ca) Lymph node metastasis-negative IDC; (Cb) Lymph node metastasis-positive IDC; (Cc) IDC stage $\leq$ I; (Cd) IDC stage >I; (Ce) IDC size $\leq 2 \mathrm{~cm}$; (Cf) IDC size $>2 \mathrm{~cm}$. (D) IHC staining showed the expression of ErbB3 in IDC. (Da) Lymph node metastasis-negative IDC; (Db) Lymph node metastasis-positive IDC; (Dc) ER-negative; (Dd) ER-positive. (E) IHC staining showed the expression of ErbB4 in IDC. (Ea) Lymph node metastasis-negative IDC; (Eb) Lymph node metastasis-positive IDC. Original magnification, x400. IDC, invasive ductal carcinoma; IHC, immunohistochemistry; ER, estrogen receptor.

FASN. Furthermore, ErbBs were markedly increased in MCF-7-MEK5 cells and tumor tissues that demonstrate EMT characteristics, and their expression was notably decreased with FASN inhibition.

Expression of FASN and ErbBs in breast IDCs and their association with clinicopathologicalparameters. FASN was localized in the cell membrane and cytoplasm of acinar and ductal epithelial cells of IDC, and its expression was positively associated with lymphatic metastasis and tumor size (Fig. 2A). The positive expression rate of FASN, as assessed by IHC, was $77.5 \%$ in all 58 IDCs evaluated, and was higher in lymphatic metastases compared with non-lymphatic metastases $(\mathrm{P}<0.05)$. In the case of tumor size, the rate of FASN positive expression in larger tumors (diameter $>2 \mathrm{~cm}$ ) was significantly higher compared with smaller tumors (diameter $\leq 2 \mathrm{~cm} ; \mathrm{P}<0.05$ ). Parameters, including age, estrogen receptor $(\mathrm{ER})$, progesterone receptor (PR) status and clinical stage 
Table II. Association between FASN expression and clinicopathological parameters in IDC.

\begin{tabular}{|c|c|c|c|c|c|c|}
\hline \multirow[b]{2}{*}{ Parameter } & \multicolumn{6}{|c|}{ FASN expression } \\
\hline & $\begin{array}{l}\text { Negative } \\
(-) n, \%\end{array}$ & $\begin{array}{l}\text { Weak-positive } \\
\text { (1+) n, \% }\end{array}$ & $\begin{array}{l}\text { Medium-positive } \\
\text { (2+) n, \% }\end{array}$ & $\begin{array}{l}\text { Strong-positive } \\
\text { (3+) n, \% }\end{array}$ & P-value & $\mathrm{n}$ \\
\hline IDC & & & & & & 58 \\
\hline Age, years & & & & & 0.840 & \\
\hline$\leq 50$ & $2(5.0)$ & $8(20.5)$ & $12(30.8)$ & $17(43.6)$ & & 39 \\
\hline$>51$ & $2(10.5)$ & $4(21.0)$ & $7(36.8)$ & $6(31.6)$ & & 19 \\
\hline Lymph node metastases & & & & & 0.025 & \\
\hline Negative & $4(16.0)$ & $5(20.0)$ & $5(20.0)$ & $11(44)$ & & 25 \\
\hline Positive & 0 & $7(21.2)$ & $14(42.4)$ & $12(36.4)$ & & 33 \\
\hline IDC stage & & & & & 0.212 & \\
\hline $0-\mathrm{I}$ & $2(22.2)$ & 0 & $3(33.3)$ & $4(44.4)$ & & 9 \\
\hline II & $2(6.3)$ & $9(28.1)$ & $9(28.1)$ & $12(37.5)$ & & 32 \\
\hline III-IV & 0 & $3(17.6)$ & $7(41.2)$ & $7(41.2)$ & & 17 \\
\hline IDC size, $\mathrm{cm}$ & & & & & 0.048 & \\
\hline$\leq 2$ & $3(16.7)$ & $7(38.9)$ & $7(38.9)$ & $1(5.5)$ & & 18 \\
\hline$>2$ & $1(2.5)$ & $5(12.5)$ & $12(30.0)$ & $22(55)$ & & 40 \\
\hline ER & & & & & 0.220 & \\
\hline Negative & 0 & $5(27.8)$ & $5(27.8)$ & $8(44.4)$ & & 18 \\
\hline Positive & $4(10.0)$ & $7(17.5)$ & $14(35.0)$ & $15(37.5)$ & & 40 \\
\hline PR & & & & & 0.538 & \\
\hline Negative & $1(5.3)$ & $5(26.3)$ & $5(26.3)$ & $8(42.1)$ & & 19 \\
\hline Positive & $3(7.7)$ & $7(17.9)$ & $14(35.9)$ & $15(38.5)$ & & 39 \\
\hline
\end{tabular}

P-value was obtained from non-parametric rank sum test. IDC, invasive ductal carcinoma; ER, estrogen receptor; PR, progesterone receptor.

were also associated with FASN expression, as differential expression was observed in these respective groups. However, the differences were not statistically significant $(P>0.05$; Table II).

ErbB1 expression was positively associated with lymphatic metastasis in IDC, and was localized in the cell membrane and cytoplasm of acinar and ductal epithelial cells of IDC (Fig. 2B). Immunohistochemistry analysis determined that the rate of positive ErbB1 expression was $72.4 \%$ in all 58 IDCs evaluated, and was higher in lymphatic metastases compared with non-lymphatic metastases (78.8 vs. 64\%; $\mathrm{P}<0.01$ ). Similarly, while an association between ErbB1 expression and age, ER and PR status and clinical stage was observed, the differences were not statistically significant ( $P>0.05$; Table III).

ErbB2 expression was positively associated with lymphatic metastasis, clinical stage and tumor size in IDC, and was localized in the cell membrane and cytoplasm of acinar and ductal epithelial cells of IDC (Fig. 2C). The rate of positive ErbB2 expression, as determined by IHC, was $65.5 \%$ in all 58 IDCs evaluated, and was higher in lymphatic metastases compared with non-lymphatic metastases ( 78.8 vs. $48 \%$; $\mathrm{P}<0.01)$. The rate of positive ErbB2 expression in advanced clinical stages (stages II, III and IV; 65.1\%) was significantly increased compared with early stages (stages $0-\mathrm{I}, 40 \%$; $\mathrm{P}<0.05$ ). The rate of ErbB2 positive expression in larger tumors (diameter $>2 \mathrm{~cm} ; 100 \%$ ) was considerably higher compared with smaller tumors (diameter $\leq 2 \mathrm{~cm}$; 83.3\%; P<0.05). Differential expression of ErbB2 in relation to patient age and ER and PR status was observed.However, the differences were not statistically significant ( $\mathrm{P}>0.05$; Table IV).

ErbB3 expression was positively associated with lymphatic metastasis and ER status in IDC, and was localized in the cell membrane and cytoplasm of acinar and ductal epithelial cells of IDC (Fig. 2D). The rate of positive ErbB3 expression was $79.3 \%$ in all 58 IDCs evaluated, but was higher in lymphatic metastases compared with non-lymphatic metastases (81.8 vs. $76 \% ; \mathrm{P}=0.01)$, and increased in ER-positive compared with ER-negative IDCs (75 vs. 39.9\%; P<0.05). Differential expression of ErbB3 in relation to patient age, tumor size, PR status and clinical stage was observed. However, the differences were not statistically significant $(\mathrm{P}>0.05$; Table $\mathrm{V})$.

ErbB4 expression was positively associated with lymphatic metastasis in IDC, and was localized in the cell membrane and cytoplasm of acinar and ductal epithelial cells of IDC (Fig. 2E). Immunohistochemistry analysis determined that the rate of positive ErbB4 expression was $60.3 \%$ in all 58 IDCs evaluated and was higher () in lymphatic metastases compared with non-lymphatic metastases (69.7 vs. 48.0\%; $\mathrm{P}<0.01)$. Differential expression of ErbB4 in relation to patient age, tumor size, ER and PR status and clinical stage was observed. However, the differences were not statistically significant (P>0.05; Table VI). 
Table III. Associations between ErbB1 expression and clinicopathological parameters in IDC.

\begin{tabular}{|c|c|c|c|c|c|c|}
\hline \multirow[b]{2}{*}{ Parameter } & \multicolumn{6}{|c|}{ ErbB1 expression } \\
\hline & $\begin{array}{l}\text { Negative } \\
\text { (-) n, \% }\end{array}$ & $\begin{array}{l}\text { Weak-positive } \\
\text { (1+) n, \% }\end{array}$ & $\begin{array}{l}\text { Medium-positive } \\
\text { (2+) n, \% }\end{array}$ & $\begin{array}{l}\text { Strong-positive } \\
\text { (3+) n, \% }\end{array}$ & P-value & $\mathrm{n}$ \\
\hline IDC & & & & & & 58 \\
\hline Age, years & & & & & 0.547 & \\
\hline$\leq 50$ & $10(25.6)$ & $15(38.5)$ & $12(30.8)$ & $2(5.1)$ & & 39 \\
\hline$>51$ & $6(31.6)$ & $5(26.3)$ & $8(42.1)$ & 0 & & 19 \\
\hline Lymph node metastases & & & & & 0.005 & \\
\hline Negative & $9(36)$ & $13(52)$ & $3(12)$ & 0 & & 25 \\
\hline Positive & $7(21.2)$ & $7(21.2)$ & $17(51.5)$ & $2(6)$ & & 33 \\
\hline IDC stage & & & & & 0.160 & \\
\hline $0-\mathrm{I}$ & $6(40)$ & $5(33.3)$ & $4(26.6)$ & 0 & & 15 \\
\hline II & $10(33.3)$ & $8(26.7)$ & $10(33.3)$ & $2(6.7)$ & & 30 \\
\hline III-IV & 0 & $7(53.8)$ & $6(46.2)$ & 0 & & 13 \\
\hline IDC size & & & & & 0.199 & \\
\hline$\leq 2 \mathrm{~cm}$ & $8(44.4)$ & $4(22.2)$ & $6(33.3)$ & 0 & & 18 \\
\hline$>2 \mathrm{~cm}$ & $8(20)$ & $16(40)$ & $14(35)$ & $2(5)$ & & 40 \\
\hline ER & & & & & 0.411 & \\
\hline Negative & $3(16.7)$ & $7(38.9)$ & $8(44.4)$ & 0 & & 18 \\
\hline Positive & $13(32.5)$ & $13(32.5)$ & $12(30)$ & $2(5)$ & & 40 \\
\hline PR & & & & & 0.166 & \\
\hline Negative & $3(15.8)$ & $6(31.6)$ & $10(52.6)$ & 0 & & 19 \\
\hline Positive & $13(33.3)$ & $14(35.9)$ & $10(25.6)$ & $2(5.1)$ & & 39 \\
\hline
\end{tabular}

P-value was obtained from non-parametric rank sum test. IDC, invasive ductal carcinoma; ER, estrogen receptor; PR, progesterone receptor.

Relevance of effect of FASN expression on ErbB1, ErbB2 and ErbB4 expression. Spearman's correlation analysis demonstrated that the correlation between FASN expression and ErbB1, ErbB2 and ErbB4 was statistically significant (FASN and ErbB1, P<0.01; FASN and ErbB2, P<0.05; FASN and ErbB4, $\mathrm{P}<0.05)$. In addition, the association between the expression of all ErbBs (ErbB1, ErbB2, ErbB3 and ErbB4) was also statistically significant $(\mathrm{P}<0.01$; Table VII).

\section{Discussion}

The present paper had three major findings from studies using breast cancer cells MCF7 and MCF-7-MEK5 cells (with EMT phenotype) in vivo and in vitro. First, it was observed that compared with MCF7 cells, mesenchymal and invasive MCF-7-MEK5 cells highly expressed FASN and ErbB1-4. In addition, ErbB1-4 expression was directly associated with FASN expression, which indicated that FASN and ErbBs may act as oncogenes, essential in promoting EMT of breast cancer cells. Secondly, it was revealed that that the expression of FASN and ErbB1-4 in IDC was associated with lymphatic metastasis. Thirdly, it was demonstrated that ErbB1, ErbB2 and ErbB4 expression wasassociated with FASN expression during EMT in MCF-7-MEK5 breast cancer cells and in breast cancer tissues. These results confirmed the hypothesis that
FASN affects the EMT phenotypes of breast cancer cells and such malignant processes as invasion and metastasis through regulating the expression of ErbB1, 2 and 4, while ErbB3 was not subjected to the regulation of FASN.

Previous studies have demonstrated that overexpression or mutation of ErbBs is associated with various types of malignant tumors (24), including breast (25), head and neck (26), pancreatic (27), spongioblastoma (28), lung (29) and gastriccancer (30) and carcinoma of the rectum (31). ErbB1 and ErbB2 in breast cancer are generally considered oncogenes and are essential for cancer cell EMT, proliferation, migration, survival and metastasis (32). ErbB1 and ErbB2 inhibitors are able to prevent EMT of cancer cells and reduce their migration and invasion (33). However, there remains great debate in the field concerning the functionality of ErbB3 and ErbB4 in tumors (17-20). Previous studies have suggested that ErbB3 functions as an oncogene $(34,35)$. ErbB3 and its ligand, heregulin- $\beta 1$, were able to promote the migration and invasion of cancer cells via activation of the phosphoinositide 3-kinase (PI3K) pathway, and induced EMT of breast cancer cells (36). Small interfering RNA-mediated inhibition of ErbB3 eliminated EMT, migration and invasion of colon cancer cells, and induced apoptosis (37). Other studies have argued that ErbB3 functions as a tumor suppressor (18,19,38-41). Decreased expression of ErbB3 was associated with a malignant change 
Table IV. Association between ErbB2 expression and clinicopathological parameters in IDC.

\begin{tabular}{|c|c|c|c|c|c|c|}
\hline \multirow[b]{2}{*}{ Parameter } & \multicolumn{6}{|c|}{ ErbB2 expression } \\
\hline & $\begin{array}{l}\text { Negative } \\
(-) n, \%\end{array}$ & $\begin{array}{l}\text { Weak-positive } \\
\text { (1+) n, \% }\end{array}$ & $\begin{array}{l}\text { Medium-positive } \\
\text { (2+) n, \% }\end{array}$ & $\begin{array}{l}\text { Strong-positive } \\
\quad(3+) \text { n, \% }\end{array}$ & P-value & $\mathrm{n}$ \\
\hline IDC & & & & & & 58 \\
\hline Age, years & & & & & 0.860 & \\
\hline$\leq 50$ & $12(30.8)$ & $2(5.1)$ & $8(20.5)$ & 17 (43.6) & & 39 \\
\hline$>51$ & $8(42.1)$ & $1(5.3)$ & $3(15.8)$ & 7 (36.8) & & 19 \\
\hline Lymph node metastases & & & & & 0.002 & \\
\hline Negative & $13(52)$ & $2(8)$ & $7(28)$ & $3(12)$ & & 25 \\
\hline Positive & $7(21.2)$ & $1(3.0)$ & $4(12.1)$ & $21(63.6)$ & & 33 \\
\hline IDC stage & & & & & 0.028 & \\
\hline $0-\mathrm{I}$ & $9(60.0)$ & $1(6.6)$ & $3(20)$ & $2(13.3)$ & & 15 \\
\hline II & $10(33.3)$ & 0 & $8(26.7)$ & $12(40)$ & & 30 \\
\hline III-IV & $5(38.5)$ & 0 & 0 & $8(61.5)$ & & 13 \\
\hline IDC size & & & & & 0.028 & \\
\hline$\leq 2 \mathrm{~cm}$ & $4(22.2)$ & $3(16.7)$ & $5(27.8)$ & $6(33.3)$ & & 18 \\
\hline$>2 \mathrm{~cm}$ & $16(40)$ & 0 & $6(15)$ & $18(45)$ & & 40 \\
\hline ER & & & & & 0.262 & \\
\hline Negative & $9(50)$ & 0 & $2(11.1)$ & $7(38.9)$ & & 18 \\
\hline Positive & $11(27.5)$ & $3(7.5)$ & $9(22.5)$ & $17(42.5)$ & & 40 \\
\hline PR & & & & & 0.282 & \\
\hline Negative & $9(47.4)$ & 0 & $2(10.5)$ & $8(42.1)$ & & 19 \\
\hline Positive & $11(28.2)$ & $3(7.7)$ & $9(23.1)$ & $16(41.0)$ & & 39 \\
\hline
\end{tabular}

P-value was obtained from non-parametric rank sum test. IDC, invasive ductal carcinoma; ER, estrogen receptor; PR, progesterone receptor.

in phenotypeinvolving EMT, invasion and metastasis of tumor cells and chemoresistance (38-41). The sensitivity of breast and pancreatic cancer cells to the anti-carcinogen elisideps in was increased with ErbB3 overexpression. In addition, drug tolerance was observed with decreased ErbB3 expression (40). ErbB3 expression was relatively low in KB and Hep-2 cells (oral and laryngeal epidermoid cancer cells, respectively) that exhibit EMT characteristics. These cells were resistant to gefitinib. However, treatment with the antineoplastic drug vorinostat was able to reverse EMT induced by upregulatedErbB3 and E-cadherin (41).

The role of ErbB4 in cancer is also controversial (18), and a number of studies have shown that ErbB4 exhibit oncogenic activity $(42,43)$. ErbB4 overexpression or mutation induced tyrosine phosphorylation and activation of downstream signaling pathways (44), and its overexpression was shown to serve a role in breast cancer oncogenesis (45). Cluster of differentiation 146-mediated modification of ErbB3 and ErbB4 expression on the surface of breast cancer cells resulted in activated signaling, increased EMT and increased drug resistance of cells (46). Other studies demonstrated that ErbB4 acts as a tumor suppressor $(47,48)$, is deficient in invasive malignant tumors, including prostate cancer, pancreatic cancer and laryngocarcinoma, and is associated with an improved prognosis in neck, ovarian and breast cancers (49). In breast cancer, high ErbB4 expression promoted the sensitivity of tumor cells to hormone therapy (50). A previous study has identified that microRNA-193a-3p/5p-mediated downregulation of ErbB4 resulted in suppression of EMT, migration and invasion of human non-small-cell lung cancer, by activation of the ErbB4/PIK3 regulatory subunit 3/mammaliantargetofrapamycin/S6 kinase 2 signaling pathway (51). The present study demonstrated that ErbB1-4 expression is directly associated with FASN expression, which indicates that FASN and ErbBs may act as oncogenes, essential in promoting EMT of breast cancer.

IHC results indicated that the rate of ErbB1 expression in IDC was 72.4 and $65.5 \%$ in ErbB2, which were slightly higher than the values reported in previous studies of in situ (14-65\%) $(52,53)$ and invasive breast cancer $(10-34 \%)(54,55)$. The rates of FASN, ErbB3 and ErbB4 expression were 75.5, 79.3 and $60.3 \%$, respectively, which were in agreement with previous findings (56-58). The present results also revealed that the levels of ErbB1, ErbB2, ErbB3 and ErbB4 were associated with each other and were consistent with the results of Abd El-Rehim et al (54) in breast cancer and that of Silva et al (59) in head and neck squamous cell carcinomas.

In addition, the present study demonstrated that the expression of FASN, ErbB1, ErbB2, ErbB3 and ErbB4 in IDC was associated with lymphatic metastasis, which confirmed the results of cytological detection analysis in the present study. Previous studies suggested that high levels of FASN (60), 
Table V. Association between ErbB3 expression and clinicopathological parameters in IDC.

\begin{tabular}{|c|c|c|c|c|c|c|}
\hline \multirow[b]{2}{*}{ Parameter } & \multicolumn{6}{|c|}{ ErbB3 expression } \\
\hline & $\begin{array}{l}\text { Negative } \\
(-) n, \%\end{array}$ & $\begin{array}{l}\text { Weak-positive } \\
\text { (1+) n, \% }\end{array}$ & $\begin{array}{l}\text { Medium-positive } \\
\text { (2+) n, \% }\end{array}$ & $\begin{array}{l}\text { Strong-positive } \\
\text { (3+) n, \% }\end{array}$ & P-value & $\mathrm{n}$ \\
\hline IDC & & & & & & 58 \\
\hline Age, years & & & & & 0.802 & \\
\hline$\leq 50$ & $8(20.5)$ & $10(25.6)$ & $14(35.9)$ & $7(17.9)$ & & 39 \\
\hline$>51$ & $4(21.1)$ & $3(15.8)$ & $9(47.4)$ & $3(15.8)$ & & 19 \\
\hline Lymph node metastases & & & & & 0.010 & \\
\hline Negative & $6(24)$ & $10(40)$ & $8(32)$ & $1(4)$ & & 25 \\
\hline Positive & $6(18.2)$ & $3(9.1)$ & $15(45.5)$ & $9(27.3)$ & & 33 \\
\hline IDC stage & & & & & 0.062 & \\
\hline $0-\mathrm{I}$ & $5(33.3)$ & $4(26.7)$ & $3(20)$ & $3(20)$ & & 15 \\
\hline II & $6(20)$ & $8(26.7)$ & $11(36.7)$ & $5(16.7)$ & & 30 \\
\hline III-IV & $1(7.7)$ & $1(7.7)$ & $9(69.2)$ & $2(15.4)$ & & 13 \\
\hline IDC size & & & & & 0.229 & \\
\hline$\leq 2 \mathrm{~cm}$ & $6(33.3)$ & $4(22.2)$ & $4(22.2)$ & $4(22.2)$ & & 18 \\
\hline$>2 \mathrm{~cm}$ & $6(15)$ & $9(22.5)$ & $19(47.5)$ & $6(15)$ & & 40 \\
\hline ER & & & & & 0.031 & \\
\hline Negative & $11(61.1)$ & $5(27.8)$ & $2(11.1)$ & 0 & & 18 \\
\hline Positive & $10(25)$ & $8(20)$ & $12(30)$ & $10(25)$ & & 40 \\
\hline PR & & & & & 0.102 & \\
\hline Negative & $2(10.5)$ & $5(26.3)$ & $11(57.9)$ & $1(5.3)$ & & 19 \\
\hline Positive & $10(25.6)$ & $8(20.5)$ & $12(30.8)$ & $9(23.1)$ & & 39 \\
\hline
\end{tabular}

P-value was obtained from non-parametric rank sum test. IDC, invasive ductal carcinoma; ER, estrogen receptor; PR, progesterone receptor.

ErbB1 $(52,54,55), \operatorname{ErbB} 2(54,55,59)$, ErbB3 $(54,55)$ and ErbB4 $(54,55,61)$ associated with lymphatic metastasis and other clinicopathological characteristics. However, other studies demonstrated that the levels of ErbB1 (62), ErbB3 and ErbB4 $(63,64)$ in breast cancer were independent of lymphatic metastasis. In the present study, a positive association was observed between ErbB2 expression and the clinical stages of IDC, tumor size and ER positivity, which was in agreement with a number of the previously published studies $(54,55,58,64)$. However, other studies have demonstrated that tumor size and clinical stages were independent of ErbB2 expression, and ErbB3 was independent of ER positivity.

Therefore, the studies regarding the association between ErbBs and clinicopathological characteristics of breast cancer appear to be inconsistent. There are several possible reasons for the differences in the findings, which are associated with variations between the studies, including: i) the use of different scoring systems of positive expression rate; ii) use of different antibodies; iii) variation in the genetic backgrounds of the study populations; iv) variations in the breast cancer subtypes collected for analysis, including in situ breast cancer, invasive breast cancer and invasive ductal carcinoma; v) different number of samples collected for analysis (between 51 and 6,046 cases) (52-66); and vi) differences in detection methods.
As oncogenes associated with metabolism, membrane microdomains composed of phospholipids generated by FASN, serve as anchoring sites for ErbBs and other receptor tyrosine kinases, and perform key roles in connecting ErbBs to downstream molecules (67). In the present study, toinvestigate the function and relevance of FASN and ErbBs in tumor cell EMT, MCF-7-MEK5 cells were treated with the FASN inhibitor cerulenin. The findings indicated that ErbB1, ErbB2 and ErbB4 levels were significantly downregulated with FASN inhibition. However, there was no effect on the levels of ErbB3. Additionally, a positive association was observed between ErbB1, ErbB2, ErbB4 and FASN expression in 58 IDC samples. Samples expressing ErbB1, ErbB2 and ErbB4 also overexpressed FASN, which suggested that ErbB1, ErbB2 and ErbB4 were associated with FASN during EMT and breast cancer malignancy.

Binding of ErbBs with their respective ligands initiates the formation homo- and heterodimers, and autophosphorylation of tyrosine residues on their intracellular domain, which activates downstream PI3K/AKT or Ras/Raf/mitogen-activated protein kinase kinase/ERK1/2 signaling pathways (68). It has been demonstrated that ErbB-mediated activation of these pathways lead to cellular changes in EMT, migration and invasion (69). Additionally, ErbB1-ErbB2 heterodimers promoted migration and invasion of MCF-10A cells (70). Overexpression of ErbB1 and ErbB2 was associated with poor prognostic 
Table VI. Association between ErbB4 expression and clinicopathological parameters in IDC.

\begin{tabular}{|c|c|c|c|c|c|c|}
\hline \multirow[b]{2}{*}{ Parameter } & \multicolumn{6}{|c|}{ ErbB4 expression } \\
\hline & $\begin{array}{l}\text { Negative (-) } \\
\text { n, } \%\end{array}$ & $\begin{array}{l}\text { Weak-positive } \\
\text { (1+) n, \% }\end{array}$ & $\begin{array}{l}\text { Medium-positive } \\
\text { (2+) n, \% }\end{array}$ & $\begin{array}{l}\text { Strong-positive } \\
\text { (3+) n, \% }\end{array}$ & P-value & $\mathrm{n}$ \\
\hline IDC & & & & & & 58 \\
\hline Age, years & & & & & 0.610 & \\
\hline$\leq 50$ & $15(38.5)$ & $13(33.3)$ & $10(25.6)$ & $1(2.6)$ & & 39 \\
\hline$>51$ & $8(42.1)$ & $4(21.1)$ & $7(36.8)$ & 0 & & 19 \\
\hline Lymph node metastases & & & & & 0.001 & \\
\hline Negative & $13(52)$ & $11(44)$ & $1(4)$ & 0 & & 25 \\
\hline Positive & $10(30.0)$ & $6(18.2)$ & $16(48.5)$ & $1(3)$ & & 33 \\
\hline IDC stage & & & & & 0.266 & \\
\hline $0-\mathrm{I}$ & $8(53.3)$ & $4(26.7)$ & $3(20)$ & 0 & & 15 \\
\hline II & $12(40)$ & $8(26.7)$ & $9(30)$ & $1(3.3)$ & & 30 \\
\hline III-IV & $3(23)$ & $5(38.5)$ & $5(38.5)$ & 0 & & 13 \\
\hline IDC size & & & & & 0.628 & \\
\hline$\leq 2 \mathrm{~cm}$ & $8(44.4)$ & $6(33.3)$ & $4(22.2)$ & 0 & & 18 \\
\hline$>2 \mathrm{~cm}$ & $15(37.5)$ & $11(27.5)$ & $13(32.5)$ & $1(2.5)$ & & 40 \\
\hline ER & & & & & 0.457 & \\
\hline Negative & $5(27.8)$ & $6(33.3)$ & $7(38.9)$ & 0 & & 18 \\
\hline Positive & $18(45)$ & $11(27.5)$ & $10(25)$ & $1(2.5)$ & & 40 \\
\hline PR & & & & & 0.118 & \\
\hline Negative & $4(21.1)$ & $8(42.1)$ & $7(36.8)$ & 0 & & 19 \\
\hline Positive & 19 (48.7) & $9(23.1)$ & $10(25.6)$ & $1(2.6)$ & & 39 \\
\hline
\end{tabular}

P-value was obtained from non-parametric rank sum test. IDC, invasive ductal carcinoma; ER, estrogen receptor; PR, progesterone receptor.

Table VII. P-values of correlation analysis of positive expression between FASN and ErbB1-4 in invasive ductal carcinoma.

\begin{tabular}{lcrrr}
\hline FASN & ErbB1 & ErbB2 & ErbB3 & ErbB4 \\
\hline FASN & 0.002 & 0.016 & 0.055 & 0.016 \\
ErbB1 & & $<0.001$ & $<0.001$ & $<0.001$ \\
ErbB2 & & & $<0.001$ & $<0.001$ \\
ErbB3 & & & & $<0.001$ \\
ErbB4 & & & & \\
\hline
\end{tabular}

P-value was obtained from Spearmen correlation analysis. FASN, fatty acid synthase.

features and decreased 5-year disease-free survival rates (55). The simultaneous overexpression of the intracellular sequence motif of ErbB1 (CYT2 mICD) and ErbB4 in a breast cancer cell line significantly increased cellular invasion (71). There is no soluble ligand for ErbB2, although it has a neuregulin domain similar to ErbB3. Therefore, ErbB2 frequently heterodimerizes with other ErbBs to promote EMT, migration, invasion and survival (72-74). Targeted inhibition of ErbB2 expression or its tyrosine kinase activity may effectively treat ErbB4-dependent breast cancer, even tumor cells which do not express ErbB2. Furthermore, silencing of ErbB2 or ErbB4 led to a significant decrease in anchorage independence and cell motility of breast cancer cells (42). Therefore, ErbB heterodimers are able to significantly increase EMT, migration and invasion of various types of tumor cells.

Previous studies have focused more on the association between FASN and ErbB1 and ErbB2 dimers in tumors (7,67,75-77), and have demonstrated that cross-talk between FASN and ErbB1-ErbB2 expression may be associated with metastasis progression in malignant ovarian cancers $(67,75,77)$. Inhibition of FASN affected the synthesis of phospholipids, which indirectly destroyed the polymerization of ErbB1 and ErbB2 on the cell membrane (10-11). There are few studies investigating the effect of FASN on the expression of ErbB3, ErbB4 and their dimers. However, studies have shown that tumors that co-express ErbB1, ErbB2 and ErbB4 present an unfavorable outcome compared with other groups (54), and ErbB3 evade inhibition by HER-family tyrosine kinase inhibitors in vitro and in tumors in vivo $(74,78)$.

Together, the present results significantly expanded the understanding of FASN and ErbB1-4 function in EMT breast cancer cells, particularly when they are over expressed, and revealed an association between FASN and ErbB1, 2 and 4 expression in vitro and in vivo. Therefore, based on the findings of the present and previously reported studies, it was 
hypothesized that the long chain fatty acid synthesized by FASN may affect the expression and function of ErbB1, ErbB2 and ErbB4, as well as their polymerized dimers, via formation of microstructures on the cell membrane, therefore regulating the process of tumor cell EMT, invasion and migration. ErbB3 may regulate EMT, invasion and metastasis of the tumor cells via a FASN-independent pathway. These results additionally indicated that it may be advantageous to inhibit FASN and ErbB1, 2 and 4 for treatment of certain subsets of patients with breast cancer who positively FASN, ErbB1, 2 or 4.

\section{Acknowledgements}

The present study was funded by a grant from Natural Science Foundation of China (grant no. J1103604). The sponsors had no role in study design, data collection and analysis, decision to publish or preparation of the manuscript. The authors thank the Immunology Laboratory of Sichuan University (Sichuan, China) for supplying breast cancer cells, and thank West China Hospital of Sichuan University (Sichuan, China) for supplying breast cancer specimens and clinicopathological characteristics materials.

\section{References}

1. Yang $\mathrm{J}$ and Weinberg RA: Epithelial-mesenchymal transition: At the crossroads of development and tumor metastasis. Dev Cell 14: 818-829, 2008.

2. Weigelt B, Peterse JL and van't Veer LJ: Breast cancer metastasis: Markers and models. Nat Rev Cancer 5: 591-602, 2005.

3. Swinnen JV, Van Veldhoven PP, Timmermans L, De Schrijver E, Brusselmans K, Vanderhoydonc F, van de Sande T, Heemers H, Heyns W and Verhoeven G: Fatty acid synthase drives the synthesis of phospholipids partitioning into detergent-resistant membrane microdomains. Biochem Biophys Res Commun 302: 898-903, 2003

4. Li J, Dong L, Wei D, Wang X, Zhang S and Li H: Fatty acid synthase mediates the epithelial-mesenchymal transition of breast cancer cells. Int J Biol Sci 10: 171-180, 2014.

5. Flavin R, Peluso S, Nguyen PL and Loda M: Fatty acid synthase as a potential therapeutic target in cancer. Future Oncol 6: $551-562,2010$

6. Hung CM, Kuo DH, Chou CH, Su YC, Ho CT and Way TD: Osthole suppresses hepatocyte growth factor (HGF)-induced epithelial-mesenchymal transition via repression of the c-Met/Akt/mTOR pathway in human breast cancer cells. J Agric Food Chem 59: 9683-9690, 2011.

7. Vazquez-Martin A, Colomer R, Brunet J, Lupu R and Menendez JA: Overexpression of fatty acid synthase gene activates HER1/HER2 tyrosine kinase receptors in human breast epithelial cells. Cell Prolif 41: 59-85, 2008.

8. Burgess AW: EGFR family: Structure physiology signalling and therapeutic targets. Growth Factors 26: 263-274, 2008.

9. Lindsey S and Langhans SA: Epidermal growth factor signaling in transformed cells. Int Rev Cell Mol Biol 314: 1-418, 2015.

10. Menendez JA, Vellon L and Lupu R: Targeting fatty acid synthase-driven lipid rafts: A novel strategy to overcome trastuzumab resistance in breast cancer cells. Med Hypotheses 64 997-1001, 2005.

11. Ravacci GR, Brentani MM, Tortelli T Jr, Torrinhas RS, Saldanha T, Torres EA and Waitzberg DL: Lipid raft disruption by docosahexaenoic acid induces apoptosis in transformed human mammary luminal epithelial cells harboring HER-2 overexpression. J Nutr Biochem 24: 505-515, 2013.

12. Menendez JA and Lupu R: Fatty acid synthase and the lipogenic phenotype in cancer pathogenesis. Nat Rev Cancer 7: 763-777, 2007.

13. Moulder SL, Yakes FM, Muthuswamy SK, Bianco R, Simpson JF and Arteaga CL: Epidermal growth factor receptor (HER1) tyrosine kinase inhibitor ZD1839 (Iressa) inhibits HER2/neu (erbB2)-overexpressing breast cancer cells in vitro and in vivo. Cancer Res 61: 8887-8895, 2001.
14. Arora A and Scholar EM: Role of tyrosine kinase inhibitors in cancer therapy. J Pharmacol Exp Ther 315: 971-979, 2005.

15. Xia W, Gerard CM, Liu L, Baudson NM, Ory TL and Spector NL: Combining lapatinib (GW572016), a small molecule inhibitor of ErbB1 and ErbB2 tyrosine kinases, with therapeutic anti-ErbB2 antibodies enhances apoptosis of ErbB2-overexpressing breast cancer cells. Oncogene 24: 6213-6221, 2005.

16. Roskoski R Jr: ErbB/HER protein-tyrosine kinases: Structures and small molecule inhibitors. Pharmacol Res 87: 42-59, 2014.

17. Gullick WJ: The c-erbB3/HER3 receptor in human cancer. Cancer Surv 27: 339-349, 1996.

18. Gullick WJ: c-erbB-4/HER4: Friend or foe? J Pathol 200: 279-281, 2003

19. Knowlden JM, Gee JM, Seery LT, Farrow L, Gullick WJ, Ellis IO, Blamey RW, Robertson JF and Nicholson RI: c-erbB3 and c-erbB4 expression is a feature of the endocrine responsive phenotype in clinical breast cancer. Oncogene 17: 1949-1957, 1998.

20. Fry WH, Kotelawala L, Sweeney C and Carraway KL III: Mechanisms of ErbB receptor negative regulation and relevance in cancer. Exp Cell Res 315: 697-706, 2009.

21. Omura $\mathrm{S}$ : The antibiotic cerulenin, a novel tool for biochemistry as an inhibitor of fatty acid synthesis. Bacteriol Rev 40: 681-697, 1976.

22. Zhou C, Nitschke AM, Xiong W, Zhang Q, Tang Y, Bloch M, Elliott S, Zhu Y, Bazzone L, Yu D, et al: Proteomic analysis of tumor necrosis factor-alpha resistant human breast cancer cells reveals a MEK5/Erk5-mediated epithelial-mesenchymal transition phenotype. Breast Cancer Res 10: R105, 2008.

23. Livak KJ and Schmittgen TD: Analysis of relative gene expression data using real-time quantitative PCR and the 2(-Delta Delta C(T)) method. Methods 25: 402-408, 2001.

24. Roskoski R Jr: The ErbB/HER family of protein-tyrosine kinases and cancer. Pharmacol Res 79: 34-74, 2014.

25. Salatino M, Schillaci R, Proietti CJ, Carnevale R, Frahm I, Molinolo AA, Iribarren A, Charreau EH and Elizalde PV: Inhibition of in vivo breast cancer growth by antisense oligodeoxynucleotides to type I insulin-like growth factor receptor mRNA involves inactivation of ErbBs, PI-3K/Akt and p42/p44 MAPK signaling pathways but not modulation of progesterone receptor activity. Oncogene 23: 5161-5174, 2004.

26. Rogers SJ, Harrington KJ, Rhys-Evans P, O-Charoenrat P and Eccles SA: Biological significance of c-erbB family oncogenes in head and neck cancer. Cancer Metastasis Rev 24: 47-69, 2005.

27. Zhang Y, Banerjee S, Wang Z, Xu H, Zhang L, Mohammad R, Aboukameel A, Adsay NV, Che M, Abbruzzese JL, et al: Antitumor activity of epidermal growth factor receptor-related protein is mediated by inactivation of ErbB receptors and nuclear factor-kappaB in pancreatic cancer. Cancer Res 66: 1025-1032, 2006.

28. Clark PA, Iida M, Treisman DM, Kalluri H, Ezhilan S, Zorniak M, Wheeler DL and Kuo JS: Activation of multiple ERBB family receptors mediates glioblastoma cancer stem-like cell resistance to EGFR-targeted inhibition. Neoplasia 14: 420-428, 2012.

29. Engelman JA, Zejnullahu K, Gale CM, Lifshits E, Gonzales AJ, Shimamura T, Zhao F, Vincent PW, Naumov GN, Bradner JE, et al: PF00299804, an irreversible pan-ERBB inhibitor, is effective in lung cancer models with EGFR and ERBB2 mutations that are resistant to gefitinib. Cancer Res 67: 11924-11932, 2007.

30. Allgayer H, Babic R, Gruetzner KU, Tarabichi A, Schildberg FW and Heiss MM: c-erbB-2 is of independent prognostic relevance in gastric cancer and is associated with the expression of tumor-associated protease systems. J Clin Oncol 18: 2201-9, 2000.

31. Lee JW, Soung YH, Seo SH, Kim SY, Park CH, Wang YP, Park K, Nam SW, Park WS, Kim SH, et al: Somatic mutations of ERBB2 kinase domain in gastric, colorectal, and breast carcinomas. Clin Cancer Res 12: 57-61, 2006.

32. Ueno NT and Zhang D: Targeting EGFR in triple negative breast cancer. J Cancer 2: 324-328, 2011.

33. Chang ZG, Wei JM, Qin CF, Hao K, Tian XD, Xie K, Xie XH and Yang YM: Suppression of the epidermal growth factor receptor inhibits epithelial-mesenchymal transition in human pancreatic cancer PANC-1 cells. Dig Dis Sci 57: 1181-1189, 2012.

34. Holbro T, Beerli RR, Maurer F, Koziczak M, Barbas CF III and Hynes NE: The ErbB2/ErbB3 heterodimer functions as an oncogenic unit: ErbB2 requires ErbB3 to drive breast tumor cell proliferation. Proc Natl Acad Sci USA 100: 8933-8938, 2003.

35. Stern DF: ERBB3/HER3 and ERBB2/HER2 duet in mammary development and breast cancer. J Mammary Gland Biol Neoplasia 13: 215-223, 2008. 
36. Smirnova T, Zhou ZN, Flinn RJ, Wyckoff J, Boimel PJ, Pozzuto M, Coniglio SJ, Backer JM, Bresnick AR, Condeelis JS, et al: Phosphoinositide 3-kinase signaling is critical for ErbB3-driven breast cancer cell motility and metastasis. Oncogene 31: 706-715, 2012.

37. Beji A, Horst D, Engel J, Kirchner T and Ullrich A: Toward the prognostic significance and therapeutic potential of HER3 receptor tyrosine kinase in human colon cancer. Clin Cancer Res 18: 956-968, 2012.

38. Ebbing EA, Steins A, Fessler E, Stathi P, Lesterhuis WJ, Krishnadath KK, Vermeulen L, Medema JP, Bijlsma MF and van Laarhoven HWM: Esophageal adenocarcinoma cells and xenograft tumors exposed to Erb-b2 receptor tyrosine kinase 2 and 3 inhibitors activate transforming growth factor beta signaling, which induces epithelial to mesenchymal transition. Gastroenterology 153: 63-76, 2017.

39. McEvoy LM, O'Toole SA, Spillane CD, Martin CM Gallagher MF, Stordal B, Blackshields G, Sheils O and O'Leary JJ: Identifying novel hypoxia-associated markers of chemoresistance in ovarian cancer. BMC Cancer 15: 547, 2015.

40. Teixidó C, Marés R, Aracil M, Ramón y Cajal S and Hernández-Losa J: Epithelial-mesenchymal transition markers and HER3 expression are predictors of elisidepsin treatment response in breast and pancreatic cancer cell lines. PLoS One 8: e53645, 2013.

41. Bruzzese F, Leone A, Rocco M, Carbone C, Piro G, Caraglia M, Di Gennaro E and Budillon A: HDAC inhibitor vorinostat enhances the antitumor effect of gefitinib in squamous cell carcinoma of head and neck by modulating ErbB receptor expression and reverting EMT. J Cell Physiol 226: 2378-2390, 2011.

42. Mill CP, Zordan MD, Rothenberg SM, Settleman J, Leary JF and Riese DJ II: ErbB2 is necessary for ErbB4 ligands to stimulate oncogenic activities in models of human breast cancer. Genes Cancer 2: 792-804, 2011.

43. Bae JA, Kho DH, Sun EG, Ko YS, Yoon S, Lee KH, Ahn KY, Lee JH, Joo YE, Chung IJ, et al: Elevated coexpression of KITENIN and the ErbB4 CYT-2 isoform promotes the transition from colon adenoma to carcinoma following APC loss. Clin Cancer Res 22: 1284-1294, 2016.

44. Prickett TD, Agrawal NS, Wei X, Yates KE, Lin JC, Wunderlich JR, Cronin JC, Cruz P, Rosenberg SA and Samuels Y: Analysis of the tyrosine kinome in melanoma reveals recurrent mutations in ERBB4. Nat Genet 41: 1127-1132, 2009.

45. Wali VB, Gilmore-Hebert M, Mamillapalli R, Haskins JW, Kurppa KJ, Elenius K, Booth CJ and Stern DF: Overexpression of ERBB4 JM-a CYT-1 and CYT-2 isoforms in transgenic mice reveal isoform-specific roles in mammary gland development and carcinogenesis. Breast Cancer Res 16: 501, 2014.

46. Imbert AM, Garulli C, Choquet E, Koubi M, Aurrand-Lions M and Chabannon C: CD146 expression in human breast cancer cell lines induces phenotypic and functional changes observed in epithelial to mesenchymal transition. PLoS One 7: e43752, 2012.

47. Liu Y, Song L, Ni H, Sun L, Jiao W, Chen L, Zhou Q, Shen T, Cui H, Gao T and Li J: ERBB4 acts as a suppressor in the development of hepatocellular carcinoma. Carcinogenesis 38 465-473, 2017.

48. Gallo RM, Bryant IN, Mill CP, Kaverman S and Riese DJ II: Multiple functional motifs are required for the tumor suppressor activity of a constitutively-active ErbB4 mutant. J Cancer Res Ther Oncol 1: 10, 2013.

49. Uberall I, Kolár Z, Trojanec R, Berkovcová J and Hajdúch M: The status and role of ErbB receptors in human cancer. Exp Mol Pathol 84: 79-89, 2008.

50. Ghayad SE, Vendrell JA, Ben Larbi S, Dumontet C, Bieche I and Cohen PA: Endocrine resistance associated with activated ErbB system in breast cancer cells is reversed by inhibiting MAPK or PI3K/Akt signaling pathways. Int J Cancer 126: 545-562, 2010.

51. Yu T, Li J, Yan M, Liu L, Lin H, Zhao F, Sun L, Zhang Y, Cui Y, Zhang F, et al: MicroRNA-193a-3p and -5p suppress the metastasis of human non-small-cell lung cancer by downregulating the ERBB4/PIK3R3/mTOR/S6K2 signaling pathway. Oncogene 34 413-423, 2015

52. Suo Z, Emilsen E, Tveit KM and Nesland JM: Type 1 protein tyrosine kinases in benign and malignant breast lesions. Histopathology 33: 514-521, 1998

53. Walker RA and Dearing SJ: Expression of epidermal growth factor receptor mRNA and protein in primary breast carcinomas. Breast Cancer Res Treat 53: 167-176, 1999.
54. Abd El-Rehim DM, Pinder SE, Paish CE, Bell JA, Rampaul RS, Blamey RW, Robertson JF, Nicholson RI and Ellis IO: Expression and co-expression of the members of the epidermal growth factor receptor (EGFR) family in invasive breast carcinoma. Br J Cancer 91: 1532-1542, 2004.

55. Badovinac-Crnjevic T, Jakic-Razumovic J,Podolski P, Pleština S, Sarčević B, Munjas R and Vrbanec D: Significance of epidermal growth factor receptor expression in breast cancer. Med Oncol 28 (Suppl 1): S121-S128, 2011.

56. Porta R, Blancafort A, Casòliva G, Casas M, Dorca J, Buxo M, Viñas G, Oliveras G and Puig T: Fatty acid synthase expression is strongly related to menopause in early-stage breast cancer patients. Menopause 21: 188-191, 2014.

57. Suo Z, Berner HS, Risberg B, Karlsson MG and Nesland JM: Estrogen receptor-alpha and C-ERBB-4 expression in breast carcinomas. Virchows Arch 439: 62-69, 2001.

58. Witton CJ, Reeves JR, Going JJ, Cooke TG and Bartlett JM: Expression of the HER1-4 family of receptor tyrosine kinases in breast cancer. J Pathol 200: 290-297, 2003.

59. Silva SD, Cunha IW, Younes RN, Soares FA, Kowalski LP and Graner E: ErbB receptors and fatty acid synthase expression in aggressive head and neck squamous cell carcinomas. Oral Dis 16: 774-780, 2010

60. Long QQ, Yi YX, Qiu J, Xu CJ and Huang PL: Fatty acid synthase (FASN) levels in serum of colorectal cancer patients: Correlation with clinical outcomes. Tumour Biol 35: 3855-3859, 2014.

61. Lodge AJ, Anderson JJ, Gullick WJ, Haugk B, Leonard RC and Angus B: Type 1 growth factor receptor expression in node positive breast cancer: Adverse prognostic significance of c-erbB-4. J Clin Pathol 56: 300-304, 2003.

62. Lewis S, Locker A, Todd JH, Bell JA, Nicholson R, Elston CW, Blamey RW and Ellis IO: Expression of epidermal growth factor receptor in breast carcinoma. J Clin Pathol 43: 385-389, 1990.

63. Chiu CG, Masoudi H, Leung S, Voduc DK, Gilks B, Huntsman DG and Wiseman SM: HER-3 overexpression is prognostic of reduced breast cancer survival: A study of 4046 patients. Ann Surg 251: 1107-1116, 2010.

64. Fujiwara S, Ibusuki M, Yamamoto S, Yamamoto Y and Iwase H: Association of ErbB1-4 expression in invasive breast cancer with clinicopathological characteristics and prognosis. Breast Cancer 21: 472-481, 2014

65. Lim ST, Yu JH, Park HK, Moon BI, Ko BK and Suh YJ: A comparison of the clinical outcomes of patients with invasive lobular carcinoma and invasive ductal carcinoma of the breast according to molecular subtype in a Korean population. World J Surg Oncol 12: 56, 2014.

66. Zengel B, Yararbas U, Duran A, Uslu A, Elıyatkın N, Demırkıran MA, Cengiz F, Simşek C, Postacı H, Vardar E and Durusoy R: Comparison of the clinicopathological features of invasive ductal, invasive lobular, and mixed (invasive ductal + invasive lobular) carcinoma of the breast. Breast Cancer 22: 374-381, 2015.

67. Grunt TW, Wagner R, Grusch M, Berger W, Singer CF, Marian B Zielinski CC and Lupu R: Interaction between fatty acid synthase- and ErbB-systems in ovarian cancer cells. Biochem Biophys Res Commun 385: 454-459, 2009.

68. Suda K, Tomizawa K and Mitsudomi T: Biological and clinical significance of KRAS mutations in lung cancer: An oncogenic driver that contrasts with EGFR mutation. Cancer Metastasis Rev 29: 49-60, 2010.

69. Stivarou T and Patsavoudi E: Extracellular molecules involved in cancer cell invasion. Cancers (Basel) 7: 238-265, 2015.

70. Zhan L, Xiang B and Muthuswamy SK: Controlled activation of ErbB1/ErbB2 heterodimers promote invasion of three-dimensional organized epithelia in an ErbB1-dependent manner: Implications for progression of ErbB2-overexpressing tumors. Cancer Res 66: 5201-5208, 2006.

71. Kiuchi T, Ortiz-Zapater E, Monypenny J, Matthews DR, Nguyen LK, Barbeau J, Coban O, Lawler K, Burford B, Rolfe DJ, et al: The ErbB4 CYT2 variant protects EGFR from ligand-induced degradation to enhance cancer cell motility. Sci Signal 7: ra78, 2014

72. Baselga J and Swain SM: Novel anticancer targets: Revisiting ERBB2 and discovering ERBB3. Nat Rev Cancer 9: 463-475, 2009.

73. Spears M, Taylor KJ, Munro AF, Cunningham CA, Mallon EA, Twelves CJ, Cameron DA, Thomas J and Bartlett JM: In situ detection of HER 2:HER 2 and HER 2:HER3 protein-protein interactions demonstrates prognostic significance in early breast cancer. Breast Cancer Res Treat 132: 463-470, 2012. 
74. Sergina NV, Rausch M, Wang D, Blair J, Hann B, Shokat KM and Moasser MM: Escape from HER-family tyrosine kinase inhibitor therapy by the kinase-inactive HER3. Nature 445: 437-441, 2007.

75. Tomek K, Wagner R, Varga F, Singer CF, Karlic H and Grunt TW: Blockade of fatty acid synthase induces ubiquitination and degradation of phosphoinositide-3-kinase signaling proteins in ovarian cancer. Mol Cancer Res 9: 1767-1779, 2011.

76. Vazquez-Martin A, Fernandez-Real JM, Oliveras-Ferraros C, Navarrete JM, Martin-Castillo B, Del Barco S, Brunet J and Menendez JA: Fatty acid synthase activity regulates HER 2 extracellular domain shedding into the circulation of HER2-positive metastatic breast cancer patients. Int J Oncol 35: 1369-1376, 2009.
77. Cai Y, Wang J, Zhang L, Wu D, Yu D, Tian X, Liu J, Jiang X, Shen Y, Zhang L, et al: Expressions of fatty acid synthase and HER2 are correlated with poor prognosis of ovarian cancer. Med Oncol 32: 391, 2015.

78. Mirschberger C, Schiller CB, Schräml M, Dimoudis N, Friess T, Gerdes CA, Reiff U, Lifke V, Hoelzlwimmer G, Kolm I, et al: RG7116, a therapeutic antibody that binds the inactive HER3 receptor and is optimized for immune effector activation. Cancer Res 73: 5183-5194, 2013. 